\title{
Potentilla $\times$ angarensis Popov (Rosaceae Juss.) - a new taxon for the Oka-Don Lowland
}

\author{
Alexey A. Kechaykin ${ }^{1}$, Anna B. Bedenko², Vladimir A. Agafonov² \\ 1 South-Siberian Botanical Garden, Altai State University, 61 Lenina Prospect, Barnaul, 656049, Russia \\ 2 Voronezh State University, Faculty of Medicine and Biology, Department of Botany and Mycology, \\ 1 Universitetskaya pl., Voronezh, 394018, Russia \\ Corresponding author: Alexey A. Kechaykin (alekseikechaikin@mail.ru)
}

Academic editor: D. German | Received 28 December 2020 | Accepted 30 June 2021 | Published 23 August 2021

http://zoobank.org/1F7DED0D-D16E-4CC0-B05B-B0CEA7FF62D7

Citation: Kechaykin AA, Bedenko AB, Agafonov VA (2021) Potentilla $\times$ angarensis Popov (Rosaceae Juss.) - a new taxon for the Oka-Don Lowland. Acta Biologica Sibirica 7: 211-218 https://doi.org/10.3897/abs.7.e62533

\begin{abstract}
A new locality of the taxon from the genus Potentilla, endemic to the flora of Russia and Kazakhstan, was discovered in Eastern Europe. Previously, P. $\times$ angarensis was recorded for the European part of Russia based on collections from Moscow Region and the Republic of Udmurtia. The paper reports the first record of this hybrid for the Oka-Don Lowland, which was found in the northeast of the Voronezh Region. The main morphological characters of the hybridogenic taxon, which distinguish it from closely related species, are listed. The general distribution of $P . \times$ angarensis is specified. An image of the herbarium specimen of the new record is presented.
\end{abstract}

\section{Keywords}

Distribution, Eastern Europe, hybridization, new record, Potentilla argentea, Potentilla tergemina, Russia, Voronezh Region

\section{Introduction}

The Oka-Don Lowland (also referred to as the Oka-Don Plain) is located in Eastern Europe in the territory of Russia and occupies a part of Ryazan, Tambov, Lipetsk, Voronezh, and Volgograd Regions, as well as the Republic of Mordovia. The plain is a vast depression located in the basins of the Oka and Don Rivers. It borders with

Copyright Alexey A. Kechaykin et al. This is an open access article distributed under the terms of the Creative Commons Attribution License (CC BY 4.0), which permits unrestricted use, distribution, and reproduction in any medium, provided the original author and source are credited. 
Central Russia in the west, with the Volga River in the east, with the SmolenskMoscow Uplands in the north, and in the south, it gradually narrows towards the mouth of the Khoper and Medveditsa Rivers. The northern part of the Oka-Don Lowland bounded by the Oka River was named the Meshchera Lowland. Its central and southern parts are named the Tambov Plain. The relief of the plain features vast plateaus with absolute heights of 160-180 m, which alternate with wide terraced valleys of the Don, Voronezh, Bityug, Khoper, Medveditsa, Tsna, Pra, and others rivers that stretch almost along the meridional direction. In addition to river valleys, the Oka-Don Lowland includes areas with varying degrees of relief dissection by ravines and gullies (Zanin 1967).

The paper reports the first record of the taxon Potentilla $\times$ angarensis Popov from the Oka-Don Lowland, which is endemic to the flora of Russia and Kazakhstan. According to the botanical geographical zoning proposed in Flora of the European Part of the USSR (Bobrov et al. 1974), the Oka-Don Lowland is located in the Volga-Don and Nizhne-Don floristic subregions of Eastern Europe. For these subregions, 27 and 21 species of the genus Potentilla are reported, respectively, with no $P . \times$ angarensis Popov recorded (Kamelin 2001). In individual regions located on the Oka-Don Lowland, the following number of species of the genus Potentilla is reported. The number of species in the flora of Volgograd Region (Reshetnikova 2018) and the Republic of Mordovia (Silaeva et al. 2010) amounts to 18, and 16 species each are found in Ryazan (Kazakova 2004), Lipetsk (Kazakova et al. 1996), and Tambov Regions (Sukhorukov et al. 2010). The number of species in the flora of Voronezh Region is 25 species (Kamyshev 1978; Tsvelev 1988; Agafonov 2006). No $P . \times$ angarensis Popov has been found in all the above regions. In the flora of Eastern Europe, this hybrid is recorded only for the Moscow Region (Vinogradova et al. 2017; Shcherbakov, Lyubeznova 2018), and the Republic of Udmurtia (Baranova, Puzyrev 2012).

\section{Material and methods}

Two interesting herbarium specimens were found during the revision of the materials of the genus Potentilla L. in the fund collections of the Herbarium named after Professor B. M. Kozo-Polyansky, Voronezh State University (VOR). Each specimen contained one plant in the bud-formation period collected in the same area. We identified these herbarium specimens using identifiers for the genus Potentilla, including the territories of Eastern Europe and Asia (Kamelin 2001; Soják 2004, 2012a). The plant was identified as $P . \times$ angarensis, a hybrid species described from Eastern Siberia. The specimens used for comparison were the type specimens stored in Herbaria A (Index of Botanical Specimens 2020); E (Rob Cubey 2018); K (Royal Botanic Gardens, Kew 2020); NSK (Kovtonyuk et al. 2020); MW (Seregin 2020); PE (China, Beijing); US (The United States National Herbarium 2020), as well as Herbarium ALTB specimens (Russia, Barnaul). The specimens collected in Voronezh 
Region were morphologically identical to $P . \times$ angarensis and materials collected in Siberia and Kazakhstan. Herbarium acronyms are listed according to Index Herbariorum (Thiers 2020).

\section{Results and discussion}

For the first time, $P . \times$ angarensis is reported for the flora of the Oka-Don Lowland. The hybrid was collected in Voronezh Region. This region is located in the central zone of the European part of Russia. The administrative-territorial division includes 31 municipal districts and three urban districts: Voronezh, Borisoglebsk, and Novovoronezh. According to the herbarium labels, plants were found near the railway station in the Borisoglebsk town on the northeast of the region. Below we present the original label (it is similar for both samples) that indicates the corresponding barcodes and provides an image of one of the herbarium specimens of $P$. $\times$ angarensis.

Herbarium label data: “Воронежская область, город Борисоглебск, ж/д станция, насыпь ж/д полотна. 1.06.2010. Разумова E.B.” [Voronezh Region, Borisoglebsk, railway station, railroad track embankment. 1 Juny 2010. E.V. Razumova]. The barcodes assigned to the herbarium specimens are VOR0005366 and VOR0005368 (Fig. 1). On the site of Herbarium VOR, the data on these samples contain the geographical coordinates corresponding to the collection site: $51^{\circ} 21^{\prime} 24.64^{\prime \prime} \mathrm{N}, 42^{\circ} 5^{\prime} 26.72^{\prime \prime} \mathrm{E}$ (Bedenko 2020). The distribution of $P$. $\times$ angarensis in the flora of Eastern Europe and specifically in the Voronezh Region is shown on the map (Fig. 2).

According to the author, $P . \times$ angarensis is a hybrid taxon resulting from crosses between $P$. multifida L. and P. impolita Wahlenb. (= P. argentea L. s. 1.) (Popov 1957). The hybrid was described based on collections from South Siberia. Below we cite the original protologue data and provide information on the type material of $P$. $\times$ angarensis.

Protologue: "4025. $\times$ Potentilla angarensis M. Pop. sp. nova $=$ P. multifida L. $\times$ P. impolita Wahlb. Foliolis tenuissime laciniatis a $P$. argentea L. et P. impolita Wahlb. distincta. M. Рopov. Иркутская обл., Ангарск, на склоне бугра в редком сосняке у дороги. Собр. М. Попов. - Prov. Irkutsk. Opp. Angarsk in pineto collucato apud viam. Leg. M. Popov. 1955 VII 23" [4025. × Potentilla angarensis M. Pop. sp. nova = P. multifida L. $\times$ P. impolita Wahlb. Foliolis tenuissime laciniatis a $P$. argentea L. et $P$. impolita Wahlb. distincta. M. Porov. Irkutsk obl., Angarsk, a hillside in a sparse pine forest near the road. Collected by M. Popov. - Prov. Irkutsk. Opp. Angarsk in pineto collucato apud viam. Leg. M. Porov. 1955 VII 23] (Popov, 1957: 18).

Type. Holotype: "4025. × Potentilla angarensis M. Pop. sp. nova = P. multifida L. $\times$ P. impolita Wahlb. Foliolis tenuissime laciniatis a $P$. argentea L. et $P$. impolita Wahlb. distincta. M. Porov. Irkutsk obl., Angarsk, on a hillside in a sparse pine forest near the road. Collected by M. Popov. - Prov. Irkutsk. Opp. Angarsk in pineto collucato apud viam. Leg. M. Porov. 1955 VII 23" (MW, MW0592742!). 


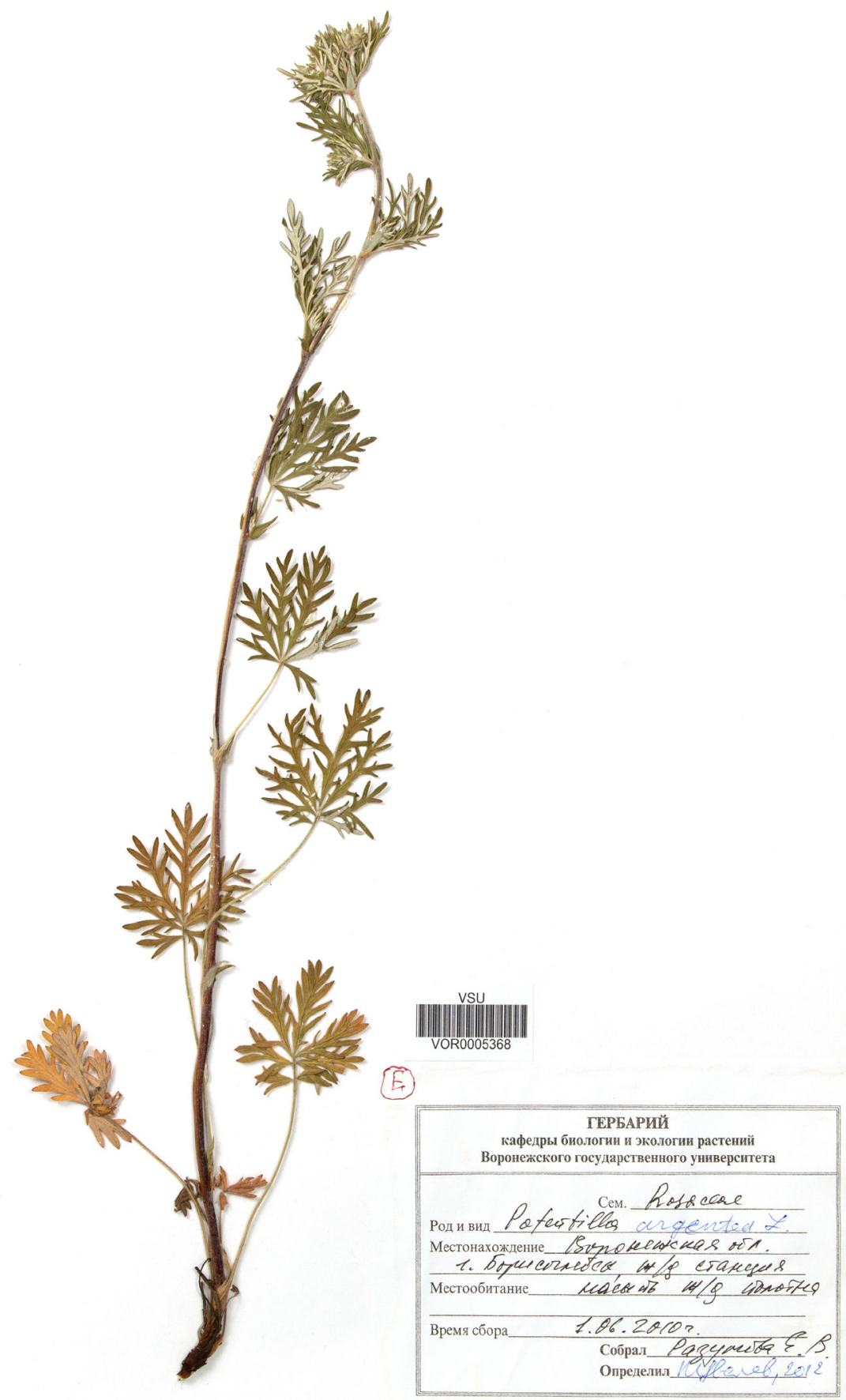

Figure 1. Herbarium specimen VOR0005368. 


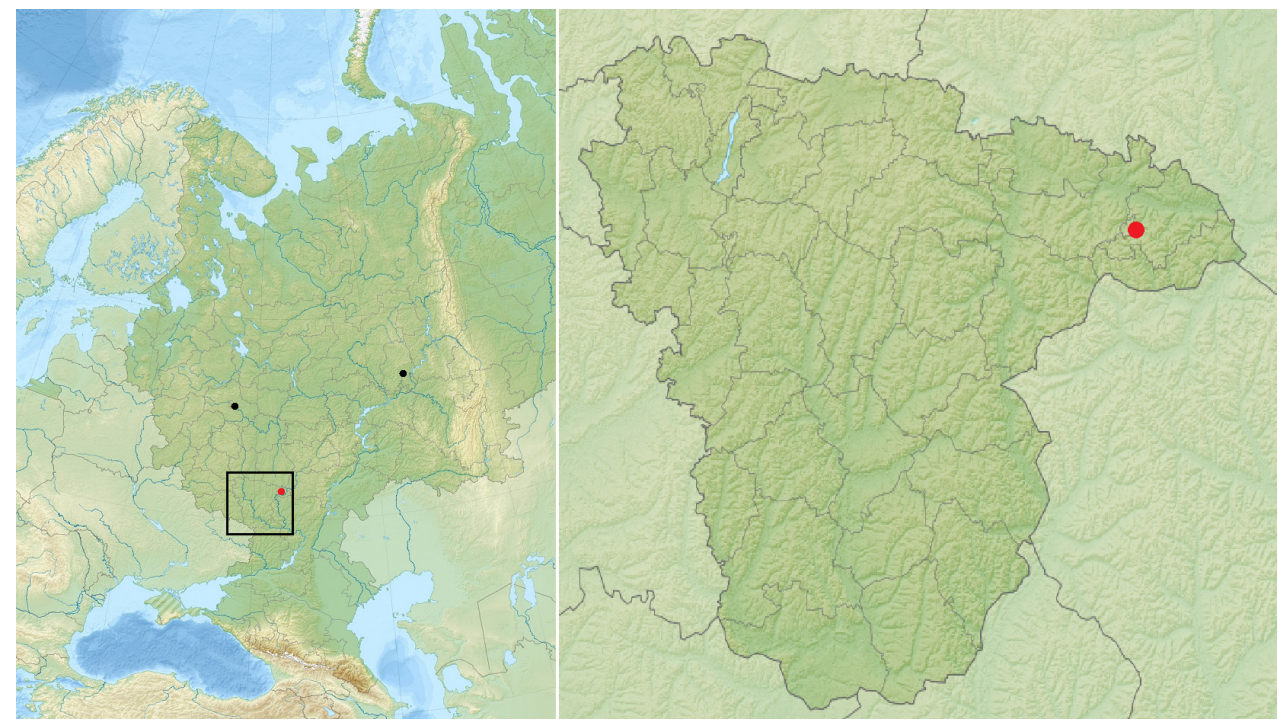

Figure 2. Distribution of $P . \times$ angarensis in the flora of Eastern Europe and specifically in Voronezh Region: black dots indicate previously known locations; a red dot indicates a new location.

Isotypes: A, A00019643; E, E00664154; K, K000762371; NSK, NSK0000713!; PE, PE01656588!; US, US00095522.

J. Soják, a well-known researcher of the genus Potentilla, in one of his works suggested that $P . \times$ angarensis could have resulted from crosses between $P$. argentea and P. tergemina Soják (Soják 1987). In this work, J. Soják (1987) described P. omissa Soják, which, in his opinion, was derived from the hybridization between $P$. argentea and P. multifida. Authentic P. omissa materials are numerous and originate from various locations in North Kazakhstan, the southern part of East Siberia, and the Russian Far East (Soják 1987). It is extremely difficult to distinguish $P . \times$ angarensis from $P$. omissa. According to J. Soják, the hair length of $P$. omissa is $0.3-1.3$ $\mathrm{mm}$, and the hair length of $P . \times$ angarensis is 1.2-2.5 mm (Soják 1987, 2004, 2009, 2012a, 2012b). Therefore, the length of petiole hairs is the only character to distinguish these closely related taxa. The length of petiole hairs of $P . \times$ angarensis collected in Voronezh Region exceeds $1.5 \mathrm{~mm}$, which corresponds to the main character distinguishing it from the closely related $P$. omissa.

Since the difference between $P . \times$ angarensis and $P$. omissa is insignificant and not always obvious, J. Soják attempted to prove their hybrid nature experimentally (Soják 1987, 2012a). The author conducted the following hybridization experiments. First, he artificially crossed the putative parental species: exact copies of the natural species $P . \times$ angarensis were obtained from hybridization between $P$. argentea and $P$. tergemina; hybrids $P$. argentea and $P$. multifida were found to be identical to specimens of $P$. omissa from natural populations studied in nature in South Siberia (Soják 1987, 2012b). 
P. $\times$ angarensis was recently reported as a new taxon for the flora of Kazakhstan, with subsequent records for East Kazakhstan Region (Kechaykin et al., 2020a, 2020b). Based on the literary data and our own data, we specify the species distribution.

General distribution. Eastern Europe: Moscow (Vinogradova et al. 2017; Shcherbakov, Lyubeznova 2018) and Voronezh Regions, the Republic of Udmurtia (Baranova, Puzyrev 2012); southern parts of West and East Siberia and the Russian Far East: from the Urals to Vladivostok (Popov 1957; Soják 1987, 2004, 2009, 2012); Kazakhstan: East Kazakhstan and Almaty Regions (Kechaykin et al., 2020a, 2020b).

The range of $P$. omissa is narrower and extends from North Kazakhstan to the southern regions of the Russian Far East (Soják 2004). According to some reports, $P$. omissa also grows in northwestern China (Soják 2012a). $P . \times$ angarensis and $P$. omissa can often be found in the areas of intersection of the populations of parental species. However, they began to spread along the roads regardless of their parents. The outbreak of these hybrid species probably co-occurred with the colonization of Siberia and the construction of roads and large oil and gas processing enterprises. Their typical habitat is grassland along the banks of water bodies and various semicultural communities along the roads. Both taxa tend to spread in areas of considerable human activity: in clear-cuts, near mines and pits, on dumps, and around construction sites.

\section{Conclusion}

In Eastern Europe $P . \times$ angarensis grows in three regions: Moscow and Voronezh Regions and the Republic of Udmurtia. It has been experimentally proven that the species resulted (and results) from hybridization between $P$. argentea and $P$. tergemina. The taxon prefers habitats subject to considerable human activity and actively spreads along roads and railways regardless of the populations of parental species. Therefore, it can be assumed with reasonable assurance that $P . \times$ angarensis can be found in many other regions from Moscow (possibly to the west) to Vladivostok, along the Trans-Siberian Railway.

\section{Acknowledgements}

We are grateful to the Curators of the following herbaria for herbarium and library facilities: NSK, MW, and PE. 


\section{References}

Agafonov VA (2006) Steppe, calcephilic, psammophilic and halophilic ecological and floristic complexes of the Middle Don basin: their origin and protection. Voronezh State University Publ., Voronezh, 250 p. [In Russian]

Baranova OG, Puzyrev AN (2012) Synopsis of the flora of the Udmurt Republic (vascular plants). Institute for Computer Research Publ., Moscow, Izhevsk, 212 p. [In Russian]

Bedenko AA (2020) Herbarium named after Professor B.M. Kozo-Polyansky, Voronezh State University (VOR). http://herbarium.bio.vsu.ru/ [Accessed on 20.10.2020]

Bobrov AE, Bobrov EG, Fedorov AA, NN Tsvelev (1974) Flora of European Part of the USSR. Vol. 1, Nauka Publ., Leningrad, 404 p. [In Russian]

Index of Botanical Specimens (2020) Harvard University Herbaria \& Libraries. https://kiki. huh.harvard.edu/databases/specimen_index.html [Accessed on 20.10.2020]

Kamelin RV (2001) Potentilla L. In: Tsvelev NN (ed.). Flora of Eastern Europe [Flora Europaeae Orientalis]. Vol. 10. St. Petersburg Chemical-Pharmaceutical Academy Publ., St. Petersburg: 394-452. [In Russian]

Kamyshev NS (1978) Flora of the Central Black Earth Region and its analysis. Voronezh State University Publ., Voronezh, 116 p. [In Russian]

Kazakova MV (2004) Flora of the Ryazan region. Russian word Publ., Ryazan, 338 p. [In Russian]

Kazakova MV, Rzhevuskaya NA, Khlyzova NYu, Aleksandrova KI, Grigorievskaya AYa (1996) Flora of the Lipetsk region. Argus Publ., Moscow, 376 p. [In Russian]

Kechaykin AA, Batkin AA, Sitpayeva GT, Vesselova PV, Osmonali BB, Shmakov AI (2020a) New data on genus Potentilla L. (Rosaceae Juss.) in the flora of Kazakhstan. Turczaninowia 23(1): 32-40. [In Russian] https://doi.org/10.14258/turczaninowia.23.1.4

Kechaykin AA, Bolbotov GA, Zaykov VF, Shmakov AI (2020b) Notes on Potentilla (Rosaceae) of Altai. 7. New findings in the flora of Kazakhstan. Turczaninowia 23(4): 10-16. [In Russian] https://doi.org/10.14258/turczaninowia.23.4.2

Kovtonyuk N, Han I, Gatilova E (2020) Central Siberian Botanical Garden Herbarium (NS, NSK). Central Siberian Botanical Garden SB RAS. https://doi.org/10.15468/5wcerp

Popov MG (1957) 4025. Potentilla $\times$ angarnsis M. Pop. sp. nova. A list of plants in the Herbarium of the flora of the USSR 14(81): 18. [In Russian]

Reshetnikova NM (2018) Potentilla L. In: Reshetnikova NM (ed.). Flora of the Lower Volga region. Dicotyledonous dicotyledonous flowering plants (Crassulaceae-Cornaceae). Vol. 2(2). KMK Scientific Publishing Partnership, Moscow: 45-65. [In Russian]

Rob Cubey (2018) Royal Botanic Garden Edinburgh Herbarium (E). Royal Botanic Garden Edinburgh. https://doi.org/10.15468/ypoair [Accessed via GBIF.org on 16.12.2020]

Royal Botanic Gardens, Kew (2020) Royal Botanic Gardens, Kew - Herbarium Specimens. https://doi.org/10.15468/ly60bx [Accessed via GBIF.org on 16.12.2020].

Seregin A (2020) Moscow University Herbarium (MW). Version 1.163. Lomonosov Moscow State University. https://doi.org/10.15468/cpnhcc [Accessed via GBIF.org on 16.12.2020] 
Shcherbakov AV, Lyubeznova NV (2018) List of taxa of vascular plants of Moscow flora. Galleya-Print Publ., Moscow, 160 p. [In Russian]

Silaeva TB, Kirjuchin IV, Czugunov GG, Ljovin KV, Majorov SR, Pismarkina EV, Ageeva AM, Vargot EV (2010) Vascular plants of the Republic of Mordovia (synopsis of flora). Mordovia University Publ., Saransk, 352 p. [In Russian]

Soják J (1987) Notes on Potentilla (Rosaceae). III. Some new taxa from Asia. Botanische Jahrbücher fur Systematik, Pflanzengeschichte und Pflanzengeographie 109(1): 25-48.

Soják J (2004) Potentilla L. (Rosaceae) and related genera in the former USSR (identification key, checklist and figures). Notes on Potentilla XVI. Botanische Jahrbücher für Systematik, Pflanzengeschichte und Pflanzengeographie 125(3): 253-340. https://doi. org/10.1127/0006-8152/2004/0125-0253

Soják J (2009) Potentilla L. (Rosaceae) in the former USSR; second part: comments Notes on Potentilla XXIV. Feddes Repertorium 120(3-4): 185-217. https://doi.org/10.1002/ fedr.200911102

Soják J (2012a) Potentilla L. (Rosaceae) and related genera in Asia (excluding the former USSR), Africa and New Guinea. Notes on Potentilla XXVIII. Plant Diversity and Evolution 130(1-2): 7-157. https://doi.org/10.1127/1869-6155/2012/0130-0060

Soják J (2012b) Copies of seven species and twenty hybrids of Potentilla (Rosaceae) obtained through experimental hybridization (Notes on Potentilla XXVI). Thaiszia 22(1): 33-48.

Sukhorukov AP, Balandin SA, Agafonov VA, Alekseev YuE, Buzunov IO, Efimov PG, Ivanenko YuA, Lazkov GA, Lindeman GV, Luferov AN, Mavrodiev EV, Nilova MV, Sennikov AN, Tatanov IV, Khlyzova NYu, Scholz H, Shcherbakov AV, Yurtseva OV (2010) The identification manual of vascular plants of the Tambov Region. Grif et Co Publ., Tula, 350 p. [In Russian]

The United States National Herbarium (2020) National Museum of Natural History. https:// naturalhistory.si.edu/research/botany/collections-access [Accessed on 22.10.2020].

Thiers BM (2020) Index Herbariorum: A global directory of public herbaria and associated staff. New York Botanical Garden's Virtual Herbarium. New York Botanical Garden, Bronx, New York, USA. http://sweetgum.nybg.org/science/ih/ [Accessed on 22.10.2020]

Tsvelev NN (1988) Flora of the Khopersky State Reserve. Nauka Publ., Leningrad, 191 p. [In Russian]

Vinogradova YuK, Bochkin VD, Mayorov SR, Teplov KYu, Barinov AV (2017) Historical flora of Moscow's Railway Junction (until 2012). Hortus Botanicus 12(12): 88-136. https://doi.org/10.15393/j4.art.2017.3402 [In Russian]

Zanin GV (1967) Oka-Don district. In IP Gerasimov et al. (eds.). Natural conditions and natural resources of the USSR: Central zone of the European part of the USSR. Nauka Publ., Moscow: 332-335. [In Russian] 